\title{
FOREIGN POLICY OF THE HOLY SEE UNDER THE PONTIFICATE OF POPE FRANCIS
}

\author{
Ivan Oshchypok \\ Postgraduate Student, Taras Shevchenko National University of Kyiv, Ukraine \\ e-mail: osiv@ukr.net, orcid.org/0000-0001-6645-8856
}

\section{Summary}

There are many religious actors in world politics, but only one of them - the Holy See represents more than one billion people, is active in politics, is the only religious organization with a special status in the UN, has full diplomatic relations with almost all countries. as an ordinary actor in the world public and political sphere.

Today, the Holy See plays an even more active role in world politics than in the past. Since the election of Pope John Paul II in 1978, the Holy See has played a prominent role in world politics. The charismatic and successful leadership of the Church is of great importance for the establishment by the Holy See of an agenda in the international arena, which is an important prerequisite for the effectiveness of its foreign policy. Playing a special role in international relations, the Holy See takes an active part in world policy-making and has all the important foreign policy resources that should not be underestimated.

This article reveals the formation of the main priorities of the foreign policy of the Holy See, based on historical and modern examples.

The structure of the article consists of four main parts, in which the Holy See is considered as a global transnational actor in world politics, the personal factor of the Pontiff in shaping the Holy See's foreign policy is studied, the main foreign policy tasks and priorities of the Holy See are solved.

Keywords: Holy See, Catholic church, Vatican state, Foreign Policy, Pope.

DOI: https://doi.org/10.23856/3836

\section{Introduction}

Today there is a rethinking of the historical process and changes in the political structure of the world. Among the characteristic trends in modern world politics are the reduction of the military component in political processes, increasing the economy, financial markets, cultural attractiveness, influence and prestige of international institutions and the growing role of the religious factor. And after the events of September 11, 2001, interest in studying religious topics and religious actors increased even more.

The Holy See, due to its unique legal personality (a combination of both state and religious components), does not have the power to influence external interests, therefore it remains to rely on what J. Nye described as "soft power" - on attractiveness moral authority recognized not only by believers, but also by the international community. At the present stage, the Holy See develops foreign policy and diplomacy, making maximum use of all types of influence at the religious level: activates forms of communication alternative to official diplomacy, uses a flexible approach to the changing conjuncture of international relations. An important role in shaping these aspects is played by the Pontiff, head of the Apostolic See (respectively, the Catholic Church and the Vatican).

The author aims to highlight the role of the Holy See in international relations and participation in this Pope Francis and to analyze the main foreign policy priorities of the Holy see. 
To test this hypothesis, the author formulated the following research objectives: 1 . Whether the Holy See as a global actor in world politics?; 2. What is this personal achievement of the Pope in this case Pope Francis; 3. Conform to the foreign policy strategy of the Holy See global issues of our time? 4. As the Holy See responds to these issues at the diplomatic level.

This article was used an interdisciplinary approach and the historical method, comparison method and system analysis. The article is based on official statements of the Holy See and Pope Francis.

\section{The Holy See is a global actor in World politics}

From the international legal definition, the Vatican and the Holy See are two different formations, each of which has international legal personality. What unites them -the person of the Pope, who is also the Supreme head of the Roman Catholic Church and the Vatican state (Otrosh, 2017).

The Holy See or Apostolic see is the Supreme spiritual authority of the Catholic Church, its transnational leadership, which has legal personality to conclude international transactions and the implementation of all diplomatic rights on the basis of power, sovereignty, and jurisdiction vested in the Pope, as head of the Roman Catholic Church and the Vatican state. International actors recognize the Holy See as a sovereign authority capable of diplomatic relations with other countries. Unlike the Vatican, which became a state in 1929, the Holy See has existed since the first days of the Church. Thus, in international relations the Holy See is an actor sui generis. As the Holy See, not Vatican city, is a party to most international agreements, he States maintain diplomatic relations, he participates in the work of international organizations and conferences, so only the Holy See must be recognized as a subject of international law is internationally the interests of the Catholic Church (Dyachenko, 2008: 7).

It is worth noting that the rugged Vatican exists as a purely technical structure for giving the Apostolic Capital territoriality, so all countries maintain diplomatic relations not with the Vatican City State, but with the Holy See. The Vatican City State participates in some limited international institutions directly related to the territory, such as the International Postal Union and the International Telecommunication Union.

The Holy See has its own TV and radio broadcasting, the press and the network of educational institutions and is the only religious organization in the world that has its own professional diplomatic service (Heviuk, 2010: 162). The Holy See includes the Roman Curia and an extensive network of ecclesiastical and diplomatic structures that oversee the work of the Church and conduct active diplomatic work throughout the world. The Curia includes the Secretariat of State, congregations, judicial tribunals, dicasteries, papal council secretariats, interdepartmental commissions, and a number of subsidiary institutions (The Roman Curia). The Secretary of State since 2013 is Pietro Parolin, who coordinates the work of all the offices of the Holy See (Reese, 1998: 174-175).

For many centuries the Holy See was headed by Europeans, mainly the Italians, the Roman Curia was composed of cardinals and of European origin. From the second half of the twentieth century it started to become a global player, which is reflected in its internal organization, which includes cardinals from all parts of the world, and now he is led by neuropace, a representative of the Western world.

In 1978, when the Pope was John Paul II, the Holy See maintained diplomatic relations with 84 States. Today the Holy See maintains diplomatic relations with 183 countries in the world and participates as member or observer in many international organizations. Among the 
international organizations in which the Holy See takes an active part, the most important is the UN and its specialized agencies and conferences. The Holy See has permanent observer status at the UN with organizations such as the international Committee of the red cross, the League of Arab States, the Palestinian authority and the Secretariat of the United Nations. Today Apostolic has observer status in more than ten international organizations, including the Council of Europe, Organization of American States, the Organization for security and cooperation in Europe and the International atomic energy Agency (Chong, 2013).

The Holy See works actively on the European continent, although he is not a member of the European Union and is not planning to join (Uchastie $v$ mezhdunarodnykh organizaczi$y a k h . .$.$) , and maintains close relations with the European States and intergovernmental regional$ organizations as the Organization for security and cooperation in Europe (OSCE) and the Council of Europe. After the appearance in 1980 of the Commission of the bishops ' conferences of the European community (COMECE), the Holy See has a new tool of political influence on the policies of the European Union. SOMECE committees dealing with social and legal issues of European foreign policy and EU enlargement, media and communications, migration and refugees, ethics of biological research, dialogue with Islam and Orthodoxy.

The internal basis of power and strength of the Holy See is the Catholic Church and her faithful. According to the published report "Global Catholicism: Trends and Forecasts" we see that in 1980 the Catholic population was more 783,5 million, in 2015 - more than $\$ 1.2$ billion Comparison of data from different years shows that since 1980, the Catholic population has more than doubled. Almost $20 \%$ of the world population are Catholics. In Asia and Africa there has been a rapid growth of the Catholic population, since 1980, the number of parishes has doubled. In North and South America, the number of parishes increased by $25 \%$, Oceania 5\% (Global Catholicism: Trends \& Forecas, 2015). All these data indicate a global shift of Christianity from North to South. Today, most Catholics in the world live in South America, Africa and Asia. And it is these regions that show positive dynamics. In 35 years, the Catholic Church remains not only the largest religious organization among Christians, but it remains the most multi-ethnic Church in the world (Global Catholicism: Trends \& Forecas, 2015).

So, the Holy see, the top of the Church organization, which oversees all the bishops of the world, many of which occur at the national or regional bishops ' meetings and conferences. Bishops, in turn, control different territorial units of the Church, including the diocese, which includes local parishes. It is worth noting that church elites have a direct influence on decision-making in the Church. In addition, the Holy See is the only part of the Church operates transnational. Conference of parishes and dioceses can act on issues of local or national importance, but of the Holy see, there are very few cases that could be considered a purely local or national. Conversely, the Holy See cannot ignore the rest of the Churches, since the implementation of the actions, the Holy See frequently use ancillary Church structures such as the monastic orders, missionary and charitable organizations that also join numerous secular social organizations - political parties, trade unions, youth, women, and other associations.

\section{The personality of the Pope in the foreign policy of the Holy See}

The Holy See is a chair, the seat of St. Peter, headed by the Pope, including his senior administrative staff, the Roman Curia. The Pope acts as a sovereign in his church, within his city-state, and especially in the international sphere. The Pope has the status of a legal entity in international relations. The personality of the Pontiff is of paramount importance in all spheres of activity of the Holy See and plays a fundamentally important role in shaping the foreign 
policy course. As for the relationship between the priorities of foreign policy and the figure of the pontiff, the former may shift with the arrival of the new Pope. The accents of foreign policy are changing, new ones are appearing, but regardless of the pontiff's personality, the existing traditional directions remain unchanged. When choosing diplomatic tools, methods of use to achieve their goals, the pontiff plays a decisive role. These statements stem from the following factors.

The Pope has biblical roots, which in itself determines his role in foreign policy. The paramount importance of the pontiff's personality is enshrined in canon law. According to which "the pope enjoys in the Church the supreme, complete, direct and universal authority" (can. 331) (Kodeks kanonicheskogo prava, 2007: 156). It also determines the politics and diplomacy of the Holy See.

The pontiff's supremacy in the Vatican's organizational structure follows even from a moral point of view, when all clergy have a special duty: to show respect and obedience to the Supreme Pontiff (Kodeks kanonicheskogo prava, 2007: 65). The pope operates within the ecclesial community, initiating dialogue with all its members. Thus, the relationship between the Ecumenical Church and the local churches is built, to which the doctrine of the primacy of the Bishop of Rome is applied. As the "supreme legislator", the pope issues laws and legislation, and has the right to approve decrees issued by the College of Bishops or the Conference of Catholic Bishops. As the "supreme administrator" of the Church, the Pope has authority over all relevant activities of this institution, as enshrined in the Apostolic Constitution Pastor Bonus (Giovanni Paolo II, 1988). In the judicial sphere, for the entire Catholic world, the Pope is the supreme judge who has the right to administer justice personally. Its jurisdiction includes all litigation relating to the protection of human rights. The decisions of the Pope are not appealed, which allows the pontiff to act completely independently of any kind of political force in the management of the Catholic Church.

The personal aspect of papal policy is extremely important because all the foreign policy of the Holy See is an expression of the ideas of the Pope. The figure of the current Pope Francis is extraordinary: he is the first pope in the history of the Western Hemisphere, the first pope in more than 1,200 years "non-European", the first Jesuit pope and the first monk in more than a century and a half. Hispanic origins and related factors, in particular his non-European worldview, influenced the formation of Pope Francis' policy and diplomacy. For the first time in the history of the Holy See, the Pope takes the name of St. Francis of Assisi, who called for the restoration of the Church after a period of decline (Vallely, 2013). St. Francis transformed the idea of monasticism by replacing a hermit monk with a missionary apostle, creating a reputation as a peacemaker and friend of the poor. The main thesis of Pope Francis is that it is impossible to solve the problem of poverty without the participation of the rich. The pontiff emphasizes that the mission of the Holy See in international politics has surpassed the sovereignty of the Westphalian style and he will do everything to change the Church (Vallely, 2013). Therefore, the Pope speaks openly about the problems that exist in the church, solves important issues that his predecessors did not dare to solve, so as not to provoke a conflict within the church between conservatives and liberals. In essence, we can say that Francis is not a name taken by the pope, but a whole project of creating a church that should be "poor, simple and pursue an evangelical goal in its policy." Therefore, Francis refused to live in the Apostolic Palace and moved to the guest residence "Santa Marta" and refused to wear the papal purple cape (Nuovo Papa: è l'argentino Jorge Mario Bergoglio, 2013).

Every action and statement of the Pope has an extraordinary impact on the state of international relations in general. Thus, the most resonant statement in 2015 was the recognition 
of the State of Palestine as the Holy See, which is still unrecognized by many European states (Vatykan vyznav Palestynu suverennoiu derzhavoiu, 2016). This step shows the readiness for dialogue and building a "bridge of peace and understanding" between Western and Eastern civilizations, especially the position of the Holy See goes against the will of the greatest actors in international relations, which testifies to the identity and independence of the Holy See.

Comparing the main features of the policy of the popes of the XX century, with the policy of the current pontiff, it is worth noting three characteristics of the policy of the current Pope, whose understanding helps to accurately identify the foreign policy priorities of the Holy See.

1. Deviation from "Eurocentrism" - for the first time the Pope is not associated with European traditions because of his Latin American origin. The Pope has the opportunity to see the problems of Europe through the prism of Latin America.

2. Departure from "ecclesiocentrism" - in addition to church affairs, the pope solves a range of social problems that the church can solve, while remaining a counselor, not a supervisor.

3. Departure from "Vatican-centricity" - The Vatican is not an unconditional center of power, emphasized by simplicity and accessibility.

\section{Foreign policy regional priorities of the Holy See}

Modern foreign policy of the Vatican was instrumentally and methodologically formed at the beginning of the pontificate of Pope John XXIII (1958-1963). Since then, the pontiffs have included in the range of their activities the usual now "openness" and "dialogue". Prior to that, the relationship was either absent or hostile. Since the Holy See does not have a documented concept of foreign policy, from a detailed analysis of the pontificate of Pope Francis, we can identify the main global and regional priorities of the Holy See in the international arena.

1. The main direction of the regional foreign policy of the Holy See is the universalization of the Roman Catholic Church. The Holy See is moving from a policy of Eurocentrism to close cooperation with Latin America, Asia and the Middle East. In the context of regional priorities, Africa is seen not in terms of bilateral cooperation with the countries of the continent, but as a vulnerable region that requires the attention of the entire world community.

2. The priority of the Holy See's foreign policy is relations with China, which is the site of the greatest evangelization, with a population of more than 1.3 billion. According to the Holy See, it is China that can change the global religious landscape in the coming decades. Until 2007, China categorically did not recognize the right of the Holy See to ordain bishops and insisted on the exclusive right of the Communist Party to be responsible for this process. Later, in 2007-2011, relations entered a phase of warming: China began to coordinate the appointment of new bishops with the position of the Holy See. However, in 2011, China revised its policy and returned to a strict ban on the Vatican's participation in the process. As a result of the compromise reached on September 22, 2018 and the signing of a classified Interim Agreement (Communiqué concerning the signing of a Provisional Agreement, 2018), Beijing recognizes 30 "underground" bishops, and the Vatican -8 ordained under the control of the Chinese party. Today there are two Catholic churches in China. The Holy See and China have signed an agreement that raises key issues of bilateral relations, namely, who has the right to elect and ordain bishops in China. The Vatican's preservation of diplomatic relations with Taiwan and the Holy See's support for Hong Kong's Catholic bishops, who support the opposition, remain problematic issues in bilateral relations. It is worth noting that the Chinese side is also interested in normalizing contacts with the Vatican, as a breakthrough in relations would be a diplomatic 
success for Xi Jinping, which would not only improve relations with Europe, but increase its authority among Catholics.

Latin America is of particular importance to the Pope, as in part he sees in it the future of human development. This is where most Catholics in the world are concentrated $-39 \%$, which is $60 \%$ of the total Latin American population (The Pontifical Yearbook 2017). A kind of recognition of the importance of this region for global Christianity was the election of the head of the Catholic Church of Latin America - Cardinal Jorge Mario Bergoglio. For the effective implementation of foreign policy tasks in the region, Pope Francis has been elected to prominent positions in the Vatican over the past few years, whose professional path was connected with Latin America. For example, in October 2013, Pietro Parolina, who had previously been the Apostolic Nuncio to Venezuela, was appointed Secretary of State of the Holy See (The talents of the priest and diplomat Fr. Pietro Parolin, 2013). In the fall of 2016, A. Abascal, a priest from Venezuela, became the General Rector of the Jesuit Order. The new General is the first in the history of this organization not from a European country, and the first, like the current Pope from Latin America (Francis, 2016). Pope Francis is often criticized for his special attention to the region" (Iwanowski, 2014).

With regard to regional policy on the European continent, it should be noted that the Holy See sees the European Union as a political project that needs to be given new life (Francis, 2016). According to Francis, Europe has lost its place in the world: "Although the European Union has become bigger and stronger, Europe looks" tired and old", the other world looks at it" coldly, with distrust and even suspicion"(Francis, 2014). To get out of the crisis, Europe needs to "return to its roots, return to real human care"(Francis, 2014). He called the priority "building Europe not around the economy, but around the defense of human rights and the sanctity of the human person and inalienable human values. The pontiff offers Europe to revive its leadership in science, art, human values and faith"(Francis, 2014). In the EU project, the consolidating role is given to the Church, which is able to turn Europe into a stable structure, to face new challenges and threats. In this regard, the Holy See sees the need to establish a dialogue with European secular society.

4 In regional policy, the Holy See puts forward the idea of urban diplomacy as an effective and influential factor in the system of international relations to solve problems of regional and international importance. According to Pope Francis, the city can become a place of "real, lively and effective politics" (Francis, 2016). This position of the Pope is obviously influenced by the idea of the Jesuit order, scientifically expressed by the German philosopher and theologian Erich Pszywara that "the idea of creating a united Europe should not be based on theoretical programs of political parties, but on the idea of cooperation between cities and towns" (Przywara, 2013: 76).

Given the Holy See's active position in the international arena, as well as the effectiveness of its diplomatic tools, it is clear that the Vatican is strengthening its presence in the international arena. The role of the Holy See in international organizations and in modern negotiating platforms is of considerable importance in the international community.

\section{Foreign policy global priorities of the Holy See}

The main foreign challenges of the Holy See are global foreign policy priorities, which are reduced to the protection of human rights and evangelization, charitable and educational activities, ecumenical and interreligious dialogue, peacekeeping and mediation, and the fight against environmental problems. 
The most important direction of the Holy See's foreign policy is peacekeeping. The Holy See promotes the renunciation of war as a means of resolving disputes between states and disarmament, and is actively involved in resolving interstate, interethnic, and interreligious conflicts, calling on the warring parties for dialogue and the restoration of peace. In practice, the position of the Apostolic Capital means support for the concept of humanitarian intervention.

Pope Francis' main peace step took place on September 1, 2013, when the Pontiff declared that "war leads to war, violence leads to violence!" (Angelus 1 sentyabrya, 2013). It is obvious that after such a statement, the Holy See decided to reconsider the Catholic concept of "just war", which has changed over the centuries. The Catechism of the Catholic Church of 1992 determines the exact conditions of legal protection by military force (verse 2309). Not afraid to challenge old church doctrines, Pope Francis welcomes discussions about the church's basic tenets of war and peace. "Faith and violence are incompatible," he repeated during a prayer meeting in the Vatican in 2013 (Papa pered "Anhel Hospodnii", 2013). Like his predecessors, he called for an end to the war, and went even further in the fight against nonviolent alternatives, calling for more active tools of "active nonviolence" (Francis, 2016a).

Given the power of modern warfare and the consequences of conflict resolution, the Holy See is trying to find a new direction for the global church (Butigan, 2016). The Conference on Nonviolence and a Just Peace: Promoting Catholic Understanding and Commitment to Nonviolence called on Pope Francis to publish an encyclical on active nonviolence, and the final text of the conference called on the Church to integrate nonviolence at all levels of the global institution, including dioceses., universities, religious orders and organizations and urged not to use the concept of "just war" (Mcelwee, 2016).

Direct mediation policy has become a key feature of Pope Francis' pontificate. This was most evident in the Holy See's diplomatic mediation in the resumption of diplomatic relations between the United States and Cuba in December 2014. It was the pontiff who played a key role in the normalization of relations between the two countries. Pope Francis personally called on Obama and Castro to end the Cold War and resume dialogue. The Pope's mediation was so successful that, for the first time since the Cold War, relations between the United States and Cuba have warmed. Noting Pope Francis' great contribution to the settlement of the US-Cuban conflict, Raoul Castro said he could become a Catholic again (Papa Rimskij vstretilsya s Raulem Kastro, 2015). The example of the "soft power" of the Holy See is obvious - the communist leader publicly declares his positive attitude towards the Church.

Proof of the peace policy was the pontiff's visit to the Holy Land in May 2014 and Pope Francis' meeting in the Vatican with Israeli President Shimon Peres and Palestinian President Mahmoud Abbas (In Vaticano l'abbraccio tra Abu Mazen e Shimon Peres, 2014). This was the first meeting between the two leaders after another failure of peace talks.

The next foreign policy of the Holy See is interreligious dialogue and ecumenical activities, which have raised trust in the Catholic Church throughout the world. Interreligious dialogue in the context of intercultural relations is currently a key challenge for the Vatican, as Catholics are religious minorities and severely persecuted in the Middle East, Asia, including India, China, and Africa. Dialogue with other religions and cultures is an urgent task of the XXI century. The pontiff is highly respected among heads of state and government (including those who considered themselves his opponents), seeks ecumenical rapprochement with other Christian denominations and is open to dialogue with representatives of all denominations (Iwanowski, 2014).

Ecumenical activity has become prominent in world political processes. By signing a joint declaration on the situation in Iraq, Syria and the Middle East, Pope Francis and Ecumenical 
Patriarch Bartholomew recognize the importance of a constructive dialogue with Islam based on mutual respect. They said: "Muslims and Christians are called to work together for justice, peace and respect for the dignity and rights of every human being, especially in regions where they once coexisted peacefully for centuries and are now tragically living together in the horrors of war" (Spilna deklaratsiia, pidpysana Papoiu Frantsyskom ta Vselenskym Patriarkhom Vartolomeiem I u Stambuli, 2014). They called on all the world's religious leaders to make every effort to strengthen interfaith dialogue to build a culture of peace.

Pope Francis called the visit to Bosnia and Herzegovina in 2015 a "pilgrimage of peace and dialogue." The main purpose of this trip was to overcome barriers between cultures and religions, as it is intertwined with different denominations and religions, and the key to a peaceful life is compromise and understanding (Papa pro sluzhinnia dukhovenstva i chernetstva $u$ Bosnii ta Hertsehovyni, 2015).

Poverty and inequality, which is a serious international problem, are becoming threatening. In conditions of global competition, the Holy See pays considerable attention to this foreign policy direction. The Pope speaks of the social duty of the leaders of the countries towards the socially vulnerable population. The pontiff calls on the world community to distribute economic goods evenly, and this is the moral duty of every state (Francis, 2015).

Focusing on poverty and social inequality, the Holy See focuses on the poorest countries in Africa and Latin America and seeks to draw the world's attention to humanitarian and social issues that they ignore. During a trip to Brazil, the pontiff personally visited hospitals, prisons and poor favelas. Because of the "trickle-down theory," which argues that the benefits of monopolies coincide with the benefits of small businesses and consumers, Pope Francis is often criticized. Latin American leaders, especially the left, respect the pontiff's harsh criticism of "wild capitalism" and its calls for social justice (Iwanowski, 2014). "For their appeals to believers, in which Pope Francis opposes cultural discrimination and strongly criticizes neoliberalism, some media outlets refer to the Pope as "the leader of the world's left" (Papa Franczisklider mirovykh levykh sil, 2016).

Climate change issues are also a priority in the Holy See's foreign policy. The Vatican is actively calling on the world community to maintain a "common home." The problem of climate change is related to issues of ethics, justice and social equality. The current situation of environmental degradation is related to ethical and social degradation. Pope Francis considers discussing this problem not only with world leaders, but also with specific people in local authorities. Thus, mayors and officials responsible for these issues were invited by the Pontiff to a conference on environmental protection (Pope Francis sends video message to UN Climate Action Summit, 2019). Pope Francis emphasizes the role of young people who "pay increased attention to the complex problems that arise as a result of an emergency (Climate crisis: what is COP and can it save the world?, 2019). Pope Francis even dedicated an entire encyclical "Laudato si” (Francesco, 2015) to environmental issues, which was welcomed not only by environmental organizations but also by UN Secretary-General Ban Ki-moon, Ecumenical Patriarch Bartholomew, who said. that "the fight against climate change cannot be waged individually. This problem requires the attention and action of all mankind, especially the rich regions of our planet. In a conversation with our dear brother Pope Francis, we agreed on the importance of the Church of the East and the West working on this topic" (Cop21: patriarca Bartolomeo: "non è troppo tardi per agire ma dobbiamo farlo subito", 2015).

Experts argue that "the encyclical was destined to go down in history as a turning point when environmental protection finally took its rightful place on a par with the dignity of human life and economic justice as the cornerstone of Catholic social teaching." 
Experts argue that "the encyclical was destined to go down in history as a turning point when environmental protection finally took its rightful place on a par with the dignity of human life and economic justice as the cornerstone of Catholic social teaching" (Allen, 2015).

In turn, according to D. Vigano, "returning to the question of the desire of the current pontiff to make as direct contact as possible with people and members of the Roman Curia in order to more effectively promote their position, he sends an encyclical personally to each cardinal with a request to read the document" (Vigano, 2015).

The pontiff's call to the leaders of COP 25 to show political will to preserve a healthy planet became important. A climatic emergency is a "challenge to civilization" that requires profound changes in the economic system. In a message to governments meeting at the annual climate summit in Madrid, the pontiff said that political leaders had done little to address the climate crisis (Climate crisis: what is COP and can it save the world?, 2019).

The Holy See's call for the protection of the environment testifies to the Pope's contradictory position in comparison with the canonical provisions. For the first time, the representatives of the Holy See declare problems that are not related to church affairs, but are of general importance to all mankind.

\section{Conclusions}

Summarizing the features of the current state of the Holy See as a global world player, we come to the following provisions and conclusions:

The Holy See has always occupied an important place in the hierarchy of world politics, and is a true global political player. The Catholic Church is the only religious structure in the world that has its own professional diplomatic service, and therefore has all the leverage to pursue successful diplomacy and foreign policy. The Holy See has a significant influence on the formation of the modern system of international relations. Its influence on the course of international life is due to the large number of Catholics in the world, as well as a clearly structured organizational and hierarchical structure of the Catholic Church.

The personality of the Pope is of paramount importance in all spheres of activity of the Holy See. The pontiff plays a significant role in shaping the foreign policy of the Apostolic Capital. As for the relationship between the priorities of foreign policy and the figure of the pontiff, the former may shift with the arrival of the new Pope. The accents of foreign policy are changing, new ones are appearing, but regardless of the pontiff's personality, the existing traditional trends remain unchanged.

In the context of increasing the influence and role of the Holy See in world politics, it is worth paying attention to the latter's interest in global issues and expanding foreign policy priorities, namely globalization, the problem of poor countries and inequality, environmental protection, nuclear non-proliferation, international terrorism and international terrorism. organizations, interreligious dialogue and ecumenical activities. Through active peacekeeping and mediation activities, the Holy See plays the role of a moral regulator of international relations, which, using both political and religious influence, changes international relations, spreads peaceful sentiments and calls for the harmonious existence of all mankind.

The foreign policy of the Apostolic Capital meets modern challenges and threats. Its priorities are dictated both by the global interests of the Holy See in promoting the position of the Catholic Church in major regions of the world, and by strengthening the moral and ethical foundations of international law and international relations in general. In its foreign policy, the Holy See seeks to achieve its goals mainly through moral and legal action, and in the modern 
system of international relations it is reduced to creating a common moral approach to man and the categories of security, justice and freedom. In the context of human interdependence, world order is achieved only if universal rights and responsibilities are respected and protected.

Formally declaring apoliticalness and alienation from political processes and politics in general, the Holy See continues to influence world politics, taking into account regional peculiarities. He is an active participant in the political process in Latin America, Asia and Africa. In Europe today, the main political issue for the Holy See is the issue of migrants. The Holy See sees the European Union as a political project in which it sees the consolidating role of the church, able to turn Europe into a stable structure, confronting new challenges and threats. In this regard, the Holy See sees the need to establish a dialogue with European secular society. The active work of the Catholic Church in South America and Africa is a vivid illustration of the new, modern approaches of the Holy See in achieving the global nature of Catholicism and entering the world as transforming the current state of affairs of Catholic civilization. South America is of particular importance to the Pope, as he partly sees in it the future of human development.

The Eastern policy of the Holy See has finally moved on, relations with Russia, China, and India have normalized. These countries complement the universality of Catholicism, which is almost half of humanity. However, the message of John Paul II about the common Christian roots of European culture from the Atlantic to the Urals and the need for Christianity to "breathe with two lungs" remains unrealized.

\section{References}

Allen J. (2015). If 'Laudato $\mathrm{Si}^{\prime}$ is an earthquake, it had plenty of early tremors. Cruxnow.com. https://cruxnow.com/church/2015/06/if-laudato-si-is-an-earthquake-it-had-plenty-of-earlytremors/ [in English].

Angelus 1 sentyabrya. Prizy 'v prekratit' vojnu v Sirii. (2013). Radio Vatikana. http:// ru.radiovaticana.va/storico/2013/09/01/angelus_1_sentyabrya._prizy'v_prekratit'_vojnu_v_ sirii/r us-724700. [in Russian].

Butigan K. (2016). Historic Vatican conference calls for nonviolence and 'just peace'. https://wagingnonviolence.org/2016/04/vatican-conference-calls-for-nonviolence-just-peacepope-francis/. [in English].

Catechism of the Catholic Church. https://www.vatican.va/archive/ENG0015/INDEX.HTM. [in English].

Chong A. (2013). The Catholic Church in International Politics. E-international relations. https://www.e-ir.info/2013/11/14/the-catholic-church-in-international-politics/. [in English]. Climate crisis: what is COP and can it save the world? (2019). The Guardian, https://www.theguardian.com/news/2019/dec/02/climate-crisis-what-is-cop-and-can-it-savethe-world. [in English].

Communiqué concerning the signing of a Provisional Agreement between the Holy See and the People's Republic of China on the appointment of Bishops. (2018). https://press.vatican.val content/salastampa/en/bollettino/pubblico/2018/09/22/180922d.html. [in English].

Cop21: patriarca Bartolomeo: "non è troppo tardi per agire ma dobbiamo farlo subito". (2015). SIR Agenzia d'informazione. https://www.agensir.it/quotidiano/2015/12/4/cop21-patriarca-bartolomeo-non-e-troppo-tardi-per-agire-ma-dobbiamo-farlo-subito/. [in Italian].

Dyachenko S. (2008). Osobennosti mezhdunarodnoj pravosub ektnosti Svyatogo prestola Moskva. [in Russian]. 
Francesco. (2015). Lettera enciclica "Laudato si" http://w2.vatican.va/content/francesco/it/ encyclicals/documents/papa-francesco_20150524_enciclica-laudato-si.html. [in Italian].

Francis. (2014).Visit of His Holiness Pope Francis to the European Parliament and to the council of Europe. Address of Pope Francis to the European Parliament. Strasbourg, France. The Holy See. http://www.vatican.va/content/francesco/en/speeches/2014/november/documents/papa-francesco_20141125_strasburgo-parlamento-europeo.html Francis. [in English]. Francis. (2015). Apostolic Journey of the Holy Father to Ecuador, Bolivia and Paraguay. The Holy See. http://www.vatican.va/content/francesco/en/speeches/2015/july/documents/ papa-francesco_20150709_bolivia-movimenti-popolari.html. [in English].

Francis. (2016). Conferral of the Charlemagne Prize. Address of His Holiness Pope Francis Sala Regia. http://w2.vatican.va/content/francesco/en/speeches/2016/may/documents/ papa-francesco_20160506_premio-carlo-magno.html. [in English].

Francis. (2016a). Message of His Holiness Pope Francis to Cardinal Peter K.A. Turkson on the occasion of the conference "Nonviolence and just peace: contributing to the catholic understanding of and commitment to nonviolence. The Holy See. http://www.vatican.va/content/ francesco/en/messages/pont-messages/2016/documents/papa-francesco_20160406_messaggio-non-violenza-pace-giusta.html. [in English].

Giovanni Paolo II. (1988). Costituzione apostolica pastor bonus sulla curia romana. Introduzione. The Holy See. http://w2.vatican.va/content/john-paul-ii/it/apost_constitutions/documents/ hf_jp-ii_apc_19880628_pastor-bonus-index.html. [in Italian].

Global Catholicism: Trends \& Forecas, Center for Applied Research in the Apostolate (CARA). (2015). https://cara.georgetown.edu/staff/webpages/Global\%20Catholicism\%20Release.pdf. [in English].

Heviuk A. (2010). Dyplomatychna diialnist Sviatoho Prestolu v suchasnykh mizhnarodnykh vidnosynakh. Naukovyi visnyk uzhhorodskoho universytetu, vypusk 14, Uzhhorod. - P. 161-165. [in Ukrainian].

In Vaticano l'abbraccio tra Abu Mazen e Shimon Peres. Il Papa: la Chiesa deve sorprendere. (2014) Il Mattino. https://www.ilmattino.it/home/papa_francesco_abu_mazen_shimon_peres_ abbraccio vaticano preghiera isra ele palestina-448498.html. [in Italian].

Iwanowski Z. (2014). El papa Francisco: giro del Vaticano hacia América Latina. - Iberoamerica, № 1. http://www.ilaran.ru/pdf/2014/Iberoamerica/IA_2014_1/Iwanowski.pdf. [in English]. Kodeks kanonicheskogo prava. (2007). http://www.vatican.va/archive/cod-iuris-canonici/russian/codex-iuris-canonici_russian.pdf. [in Russian].

Mcelwee J. (2016). Landmark Vatican conference rejects just war theory, asks for encyclical on nonviolence. National Catholic Reporter. https://www.ncronline.org/news/vatican/landmark-vatican-conference-rejects-just-war-theory-asks-encyclical-nonviolence. [in English].

Nuovo Papa: è l'argentino Jorge Mario Bergoglio. Si chiamerà Francesco. (2013). il Fatto Quotidiano. https://www.ilfattoquotidiano.it/2013/03/13/nuovo-papa-jorge-mario-bergoglio/ 529319\%. [in Italian].

Otrosh M. (2017). Mistse i rol Katolytskoi tserkvy u mizhnarodnomu pravoporiadku. Odesa. [in Ukrainian].

Papa Franczisk - lider mirovykh levykh sil. (2016). Narodnyj correspondent. https://nk.org.ual mir/papa-frantsisk-lider-mirovyih-levyih-sil-64282. [in Russian].

Papa pered "Anhel Hospodnii" 18.08.2013 r.: vira - ne dekoratyvna rich. (2013). Papa Frantsysk. http://popefrancis.org.ua/? $p=1176$. [in Ukrainian].

Papa pro sluzhinnia dukhovenstva $i$ chernetstva u Bosnii ta Hertsehovyni. (2015). Radio Vatykan. http://www.archivioradiovaticana.va/storico/2015/06/06/papa_pro_sluzhinnia_dukhovenstva_i_chernetstva_u_bosnii_ta_hertsehovyni/uk-1149704. [in Ukrainian]. 
Papa Rimskij vstretilsya s Raulem Kastro. Livejournal. https://hanber.livejournal.com/3364705. html. [in Russian].

Pope Francis sends video message to UN Climate Action Summit. (2019). Vatican news, https://www.vaticannews.va/en/pope/news/2019-09/pope-francis-videomessage-climate-action-summit-united-nations.html. [in English].

Przywara E.(2013). L'idead'Europa. La crisi di ogni politica cristiana”. Il Pozzo di Giacobbe. [in Italian].

Reese S., Thomas J. (1998). Inside the Vatican: The Politics and Organization of the Catholic Church. Cambridge. [in English].

Spilna deklaratsiia, pidpysana Papoiu Frantsyskom ta Vselenskym Patriarkhom Vartolomeiem I u Stambuli. (2014). Informatsiinyi resurs Ukrainskoi Hreko-Katolytskoi Tserkvy. http://news.ugcc.ua/documents/spilna_deklaratsiya_pidpisana_papoyu_frantsiskom_ta_vselenskim_patrarhom_vartolomeiem_u_stambuli_72224.html/ [in Ukrainian].

The Pontifical Yearbook 2017 and the "Annuarium Statisticum Ecclesiae” 2015. (2017). https://press.vatican.va/content/salastampa/en/bollettino/pubblico/2017/04/06/170406e.html. [in English].

The Roman Curia, Gcatholic.org. http://www.gcatholic.org/dioceses/romancuria.htm. [in English]. The talents of the priest and diplomat Fr. Pietro Parolin. (2013). Lastampa. https://lastampa.it/ 2013/08/30/vaticaninsider/the-talents-of-the-priest-and-diplomat-fr-pietro-parolinzk3OZ5125HIVWEFupiRTAI/pagina.html. [in Italian].

Uchastie $v$ mezhdunarodnykh organizacziyakh, osnovnye vneshnepoliticheskie kontragenty, otnosheniya s Rossiej. Politicheskij atlas sovremennosti. http://www.hyno.ru/tom1/395.html. [in Russian].

Vallely P. (2013). Pope Francis: Not so much a reformer as a revolutionary. The Independent. https://www.independent.co.uk/news/world/europe/pope-francis-not-so-much-a-reformer-asa-revolutionary-8845052.html. [in English].

Vatykan vyznav Palestynu suverennoiu derzhavoiu. (2016). Deutsche Welle. https://www.dw.com/ uk/vatykan_vyznav_palestynu_suverennoiu_derzhavoiu/a-18955763. [in Ukrainian].

Viganò D. (2015). Fedeltà è cambiamento. La svolta di Francesco raccontata da vicino. Roma: Rai Eri. [in Italian]. 